\title{
Crop Performance and Soil Properties under Organic Nutrient Management
}

\author{
C. K. Dotaniya ${ }^{1,2 *}$, D. S. Yashona ${ }^{2}$, S. B. Aher ${ }^{2}$, P. S. Rajput ${ }^{2}$, \\ R. K. Doutaniya ${ }^{3}$, M. Lata ${ }^{4}$ and S. Mohbe \\ ${ }^{1}$ College of Agriculture, S.K. Rajasthan Agricultural University, \\ Bikaner 334 006, Rajasthan, India \\ ${ }^{2}$ ICAR-Indian Institute of Soil Science, Bhopal 462038, Madhya Pradesh, India \\ ${ }^{3}$ ICAR-Directorate of Rapeseed Mustard Research, Sewar, \\ Bharatpur - 321303, Rajasthan, India \\ ${ }^{4}$ Rajasthan University, Jaipur, 302004 (Rajasthan), India \\ *Corresponding author
}

\section{A B S T R A C T}

\section{Ke ywords \\ Organic farming, \\ Nutrient \\ management, Crop \\ performance, Soil \\ fertility, Soil health, \\ Soil microbial \\ activity}

Article Info

Accepted:

10 March 2020

Available Online:

10 April 2020

\begin{abstract}
The agricultural production in sufficient quantities in a sustainable way is the today's greatest challenge. The sustainable way here means without deteriorating the soil health. In current scenario, the cultivation of high yielding varieties with synthetic fertilizer and agrochemicals helping to produce required food demand of growing population but indiscriminate and imbalanced use of agrochemicals imparting negative effect on soil productivity, environmental health and food quality. It is therefore, important to use appropriate production system that produces good quality food in sufficient quantities without degrading the soil and polluting environment. The organic nutrient management favors soil health sustenance and environmental protection. However, the system has always been criticized for limitations with respect to crop performance in terms of yield. The subsequent modification and integration in organic nutrient management system increased its efficiency. The studies indicating the importance and benefits of organic nutrient management towards agricultural production and soil health sustenance has been reviewed in present work. The comprehensive review revealed that the organic nutrient management either sole or integrated is essential for optimum crop production and improving soil properties.
\end{abstract}

\section{Introduction}

Agriculture sector is the principal source of livelihood for more than $58 \%$ of the population and its contribution to the national GDP is $14.2 \%$ (DOA, 2019). India has only
$2.3 \%$ share in world's total land area and has to ensure food security of about $17.5 \%$ of world population. Rapidly increasing population, shrinking land resources for crop production are putting tremendous pressure on land resource due to intensive cultivation 
(Verma et al., 2012). To meet the challenge, the farmers are forced to apply agrochemicals to adopted high yielding varieties. Fertilizers play an important role to meet nutrient requirement of the crop but their continuous use on lands will have deleterious effects on physical, chemical and biological properties of soil, which in turn reflects on yield.

Before the introduction of inorganic fertilizer manure was the primary source of nutrients for crop production. The long term and imbalanced chemical fertilizer and agrochemical application reported stagnation of crop yield and deterioration of soil health in terms of chemical and biological properties (Khandagle et al., 2019a; Raghuveer et al., 2017; Rajput et al., 2016). Similarly, the cost of fertilizers has also increased which limits their application by farmers.

Considering the scenario, farmers wish to revisit the earlier nutrient management practices, but the limited nutrient supply capacity and bulk nature of organic inputs restricts them. The recent developments in organic nutrient supply packages either sole or integration there has been a renewed interest in use of organic nutrition. The interest is attributed to concerns for maintaining sustainable agricultural production while preserving the environment (Aher et al., 2012).

Judicious application of nutrient especially organic manures not only improves the productivity (Sushila and Giri, 2000) and quality (Aher et al., 2018b; Yashona et al., 2018c) but also make cultivation sustainable (Wanjari et al., 2004) because it is the basic source of soil organic matter. Soil organic matter plays pivotal roles in several processes of the soil ecosystem including nutrient cycling, soil structure formation, carbon sequestration, water retention and energy supply to microorganisms (Lakaria et al.,
2012). In present work, the research findings related to the effect of organic nutrient management either sole or integrated on crop performance and soil properties has been reviewed.

\section{Crop performance under organic nutrient management}

The organic nutrient for agriculture involves farm yard manure, cattle dung manure, poultry manure, pig manure, compost, vermicompost, city waste compost, municipal solid waste compost, green manure etc. Organic manure plays an important role in improving soil permeability to air and water and water stable aggregates. Thus application of organic materials such as farmyard manure considerably improves soil physical properties and nutrient uptake resulting in greater growth, yield and yield components (Satyanarayana et al., 2002).

Organic nutrient application not only helps in maintaining soil health but also ensure sustainable crop production. Devi et al., (2013) reported that the crop management through organic inputs produced significantly higher number of pods per plant and seed yield of soybean than inorganic and integrated practice. Similarly, the soybean showed $9.95 \%$ higher yield under organic sources of nutrients as compared to the application of inorganic fertilizers.

The increase in yield might be due to increased biological nitrogen fixation and solubilization of more amount of $\mathrm{P}$ by phosphate solubilizing bacteria and organic manure (FYM) also acts as a substrate for microorganisms and improved soil condition favorable for availability of nutrients to crop throughout the growth period (Dotaniya et al., 2014; Prajapat et al., 2014). Ramesh et al., (2008) conducted a field experiment during 2004-05 to 2007-08 on deep Vertisols of 
Bhopal and observed that, organic manure treatment recorded significantly higher seed yields, which were 10.6 and $11.2 \%$ higher than the chemical fertilizers. Significant increase in the yield of maize (Ali et al., 2014; Mandale et al., 2018c, 2018a), pigeon pea (Yashona et al., 2018a) and wheat (Aher, 2018; Bhattacharyya et al., 2008) with the application of organic nutrients has already been reported.

Hellal et al., (2014) reported that the application of farmyard manure (FYM) influenced significantly the yield components of faba bean compared to mineral fertilizer, town refuse and biogas manure. Application of $5 \mathrm{t}$ FYM ha ${ }^{-1}$ improve plant growth and yield attributes of chickpea either numerically or significantly and increase grain yield over no application of FYM (Singh et al., 2012). Davari and Sharma (2010) have previously reported a beneficial effect of FYM on wheat. Nutrient management plays a key role in improving crop yield with maintenance of soil fertility for sustainable production in intensive cropping.

Nutrient supplied to crop/plant in organic agriculture is differently viewed than in conventional agriculture. Datt et al., (2013) reported the increase in organic carbon under the application of organic sources of nutrients. (Kanwar et al., 2002) reported that application organic manure alone recorded higher organic carbon content than chemical fertilizers (NPK) applied treatments. The application of organic sources of nutrients also reported for higher uptake of nutrients in maize (Mandale et al., 2019a), soybean (Aher et al., 2019b), garlic (Raghuveer et al., 2017), rice (Rajput et al., 2016) and pigeon pea (Yashona et al., 2018b). The higher uptake of nitrogen (Mandale et al., 2019a), phosphorous (Mandale et al., 2019b) and potassium (Mandale et al., 2018b) under organic nutrient management has also been reported. Ali et al.,
(2015) reported that the application of phosphorus at the of $120 \mathrm{~kg} \mathrm{ha}^{-1}$ results in higher biomass yield (12753 $\left.\mathrm{kg} \mathrm{ha}^{-1}\right)$.

\section{Soil properties under organic nutrient management}

\section{Soil physic-chemical properties}

Organic farming systems rely on the management of soil organic matter which has greater influence on soil fertility, soil biological, physical and chemical properties of soil which in turn reflects in to crop yield and sustainability of system. Overexploitation of soils over many decades has resulted in the exhaustion of the agricultural production systems and steadily declining productivity (Manna et al., 2005).

Therefore, long-term sustainability and overall productivity of cropping systems are directly related to the maintenance of soil organic matter (Swarup, 2010). Organic manures are the greatest source of soil organic matter that influences the soil properties and its overall health. Ramesh et al., (2008) reported that the application of organic manures significantly improved the soil organic carbon content compared to chemical fertilizers. The increase in soil organic carbon with the application of organic manure can be attributed to addition of higher biomass to the soil as of crop stubbles and residues. Increased soil organic carbon of soil due to application of manure was also previously.

Similarly, the soil nutrient availability is governed by soil adsorption and mineralization behavior (Mishra et al., 2014; Yashona et al., 2016). Rama Lakshmi et al., (2011) observed that the accumulation of organic carbon was higher in the plot where farmyard manure was applied. The enhanced organic carbon increases the soil aggregation and physical properties (Aher et al., 2019a). 
Bayu et al., (2006) also concluded that farm yard manure application increased soil organic carbon content by up to $67 \%$ over the control treatment. Long-term application of FYM contributed to the accumulation of organic matter in soil (Pikuła and Rutkowska, 2014). Singh et al., (1999) reported that the continuous application of chemical fertilizer, decrease the organic carbon content in soil, where addition of $5 \mathrm{t} \mathrm{FYM} \mathrm{ha}{ }^{-1}$ along with fertilizer $\mathrm{N}$ helped in maintaining the original organic matter status in soil. The application of manure plays important role in improving soil organic matter (Mugwe et al., 2009).

Long-term application of organic manures improved the soil organic carbon, available $\mathrm{N}$, $\mathrm{P}$ and $\mathrm{K}$ in soil, thereby sustaining the soil health (Ramesh et al., 2009). The nitrogen dynamics in soil is also governed by the soil organic matter. The application of farm yard manure reported for higher plant available nitrogen fraction in soil (Khandagle et al., 2019b). Antil and Singh (2007) concluded from their study the application of organic manure alone or with NP fertilizers for 10 years resulted in an increased organic $\mathrm{C}$ content, available NPK and significant increase in DTPA extractable $\mathrm{Zn}, \mathrm{Mn}, \mathrm{Fe}$ and $\mathrm{Cu}$. The increase in available $\mathrm{N}$ content with the addition of organic manures might be due to the release of nitrogen through the decomposition of organic manures.

Nagar et al., (2016) reported that $\mathrm{pH}$ and EC reduced slightly with application of FYM and crop residues while significantly higher organic carbon, available nitrogen and potassium were recorded in FYM + phosphocompost and pigeonpea stalk + phosphocompost over RDF alone. Long-term manuring and fertilization registered significant increase in available soil organic carbon, total $\mathrm{N} \mathrm{P}, \mathrm{K}$ and $\mathrm{S}$ in the plots under $100 \%$ NPK + farmyard manure at 10 ton/ha (Katkar et al., 2011). Singh et al., (2005) concluded that the favorable soil conditions under treatments receiving organic manures might have helped in the mineralization of soil $\mathrm{N}$ leading to increase in available $\mathrm{N}$ content. Mann et al., (2006) reported that available phosphorus content increased due to addition of FYM over initial and control. Beneficial role of FYM in improving the soil available $\mathrm{P}$ has long been observed and well established (Swarup, 2010).

The increase in available $\mathrm{P}$ of the soil resulting from the application of organic manures may be due to the mineralization of organic $\mathrm{P}$, the production of organic acids which have a solubilizing effect on soil $\mathrm{P}$ and the organic amino which retard the fixation of phosphorus in soil (Gupta et al., 1992). Sienkiewicz et al., (2009) concluded that the application of manure for several years led to a three-fold increase in the available forms of potassium in soil as compared to the content determined after the application of mineral fertilization.

The higher availability of potassium may be due to beneficial effect of organic manures on the reduction of potassium fixation, added organic matter interacted with $\mathrm{K}$ clay to release $\mathrm{K}$ from non-exchangeable fraction to the available pool. The significant increase in the contents of potassium, calcium and magnesium in the surface layer of the soil after applying manure and slurry for many years (Edmeades, 2003). Bhattacharyya et al., (2008) reported significant influence of organic manures application on soil micronutrient status as compared to conventional fertilizers application. Chaudhary and Narwal (2005) also reported that application of FYM significantly increased the DTPA extractable $\mathrm{Zn}, \mathrm{Mn}, \mathrm{Fe}$ and $\mathrm{Cu}$. Application of farm yard manure significantly increased the concentration of $\mathrm{Zn}, \mathrm{B}$ and $\mathrm{Fe}$ in the soil solution (Pikuła and Rutkowska, 2014). 
Singh Brar et al., (2015) concluded that the organic matter after decomposition release macro- and micronutrients to the soil solution, which becomes available to the plants, resulting in higher uptake.

Organic farming was capable of sustaining higher crop productivity and improving soil quality and productivity by manipulating the soil properties on long term basis. It was reported that organic and low-input farming practices after 4 years led to an increase in the organic carbon, soluble phosphorus, exchangeable potassium, and $\mathrm{pH}$ and also the reserve pool of stored nutrients and maintained relativity stable EC level.

Urkurkar et al., (2010) concluded that supply of 100 per cent nitrogen in a rice-potato cropping system $1 / 3^{\text {rd }}$ each from cow dung manure, neem cake, and composed crop residue appreciably increased the organic carbon $\left(6.3 \mathrm{~g} \mathrm{~kg}^{-1}\right)$ over initial value $\left(5.8 \mathrm{~g} \mathrm{~kg}^{-1}\right)$ as compared to supply from inorganic fertilizers alone.

\section{Soil biological properties}

The organic matter present in soil serves as food and shelter for microorganisms. The microbes can survive on different carrier material (Argal et al., 2015). Nakhro and Dkhar (2010) observed maximum microbial population counts (fungal and bacterial) and microbial biomass carbon in organically treated plot followed by the inorganically treated plot and control. Mandic et al., (2011) recorded highest count of soil microorganisms in solid manure treatment, which was significantly higher than that in the control and other fertilization treatments.

Dubey et al., (2014) reported significant increase in population of fungi, bacteria, azotobacter, PSB and actinomycetes under $100 \%$ organic as compared to $100 \%$ inorganic nutrient management. Mader (2002) found higher microbial biomasses (Cmic), enzymatic activities and lower $\mathrm{CO}_{2}$ values in organic than in plots under integrated management in a field trial. Aher et al., (2018a) recorded $27-102 \%$ and $30-45 \%$ higher enzymatic activities and soil microbial biomass carbon, respectively under organic agriculture management as compared to inorganic agriculture management. Application of organic and inorganic treatments influences the rhizosphere microbial population.

The application of vermicompost resulted in most pronounced growth of microbial population compared to inorganic treatment (Das and Dkhar, 2011). Sudhakaran et al., (2013) concluded that the $\beta$ - glucosidase activities, soil respiration and microbial population (bacteria, fungi, actinimycetes, beijerinckia, azotobacter, rhizobium, bacillus and phosphobacteria) were higher in soils from organic farming than conventional farms.

Chang et al., (2007) revealed that the soil microbial biomass, populations of bacteria, fungi and actinomycetes, as well as soil enzyme activities (dehydrogenase, acid and alkaline phosphatase) increased significantly in the compost-treated soils compared with the chemical fertilizer treated soil. Soil enzyme activities commonly correlate with microbial parameters and have been shown to be a sensitive index of long-term management effects such as crop rotations, animal and green manures and tillage (Bandick and Dick, 1999).

A higher level of dehydrogenase activity was observed in soil treated with vermicompost and manure compost compared with soil treated with mineral fertilizer has been reported. The positive effect of FYM addition on enzyme activities has been observed by 
Böhme et al., (2005). Datt et al., (2013) reported that the dehydrogenase activity was significantly higher in organic and integrated treatments than the chemical one. Singh et al., (2008) observed similar effect of organic manure.

FYM increases the activity because of its high biodegradability and micro-organisms addition. High dehydrogenase and phosphatase activity with application of FYM is attributed to higher content of organic matter.

Dehydrogenase is present in viable cells, and it is thought to reflect the total range of oxidative activity of soil microflora (Mandal et al., 2007). Soil biological activity in terms of dehydrogenase and alkaline phosphatase enzyme were observed higher in organic manured compared to chemical either fertilizer or control treatments. Ramesh et al., (2008) reported similar effect of increased enzyme activity of soil with the application of organic manures to pigeon pea crop. The phosphate activity was increased by the addition of organic materials.

Application of organic materials such as chicken manure, sheep manure and filter mud cake are emphasized by their beneficial effects on soil characteristics, macro and micronutrients availability and plant growth. Application of combined organic manures and effective microorganisms was positively affected of growth and yield of wheat plant (Brennan and Acosta-Martinez, 2019).

A comprehensive review of organic nutrient application either alone or integrated enhances the soil organic carbon. The soil organic carbon acts as a source of food and shelter for microorganisms. The increased microbial population and enzyme activities results in higher nutrient availability which reflected in terms of better crop performance.

\section{References}

Aher, S.B., 2018. Soil carbon dynamics and crop performance under organic farming. Lambert Academic Publishing, Germany.

Aher, S.B., Lakaria, B.L., Kaleshananda, S., Singh, A.B., Ramana, S., Thakur, J.K., Biswas, A.K., Jha, P., Manna, M.C., Yashona, D.S., 2018a. Soil microbial population and enzyme activities under organic, biodynamic and conventional Agriculture in Semi-Arid Tropical Conditions of Central India. J. Exp. Biol. Agric. Sci. 6, 763-773. https://doi.org/10.18006/2018.6(5).763. 773

Aher, S.B., Lakaria, B.L., Singh, A.B., Kaleshananda, S., 2019a. Soil aggregation and aggregate associated carbon in a Vertisol under conventional, organic and biodynamic agriculture in semi-arid tropics of Central India. J. Indian Soc. Soil Sci. 67, 183-191. https://doi.org/10.5958/09740228.2019.00019.7

Aher, S.B., Lakaria, B.L., Singh, A.B., Swami, K., Ramana, S., Ramesh, K., Thakur, J.K., Rajput, P.S., Yashona, D.S., 2019b. Effect of organic sources of nutrients on performance of soybean (Glycine max). Indian J. Agric. Sci. 89, 1787-1791.

Aher, S.B., Lakaria, B.L., Singh, A.B., Swami, K., Yashona, D.S., 2018 b. Nutritional quality of soybean and wheat under organic, biodynamic and conventional agriculture in semi-arid tropical conditions of Central India. Indian J. Agric. Biochem. 31, 128-136. https://doi.org/10.5958/09744479.2018.00022.9

Aher, S.B., Swami, B., Sengupta, B., 2012. Organic agriculture: Way towards sustainable development. Int. J. Environ. Sci. 3, 209-216. 
https://doi.org/10.6088/ijes.2012030131 021

Ali, A., Sharif, M., Wahid, F., Zhang, Z., Shah, S.N.M., \&nbsp, R., Zaheer, S., Khan, F., Rehman, F., 2014. Effect of Composted Rock Phosphate with Organic Materials on Yield and Phosphorus Uptake of Berseem and Maize. Am. J. Plant Sci. 05, 975-984. https://doi.org/10.4236/ajps.2014.57110

Ali, K., Jan, A., Amanullah, Khan, M.J., 2015. Pheno-morphological traits of Canola as influenced by nitrogen and green manuring crops (species, parts and age) under semiarid condition. Pure Appl. Biol. 4, 362-274. https://doi.org/10.19045/bspab.2015.43 012

Antil, R.S., Singh, M., 2007. Effects of organic manures and fertilizers on organic matter and nutrients status of the soil. Arch. Agron. Soil Sci. 53, 519528 .

https://doi.org/10.1080/0365034070157 1033

Argal, M.S., Rawat, A.K., Aher, S.B., Rajput, P.S., 2015. Bioefficacy and shelf life of Rhizobium leguminosarum loaded on different carriers. Appl. Biol. Res. 17, 125-131. https://doi.org/10.5958/09744517.2015.00017.8

Bandick, A.K., Dick, R.P., 1999. Field management effects on soil enzyme activities. Soil Biol. Biochem. 31, 1471-1479.

https://doi.org/10.1016/S00380717(99)00051-6

Bayu, W., Rethman, N.F.G., Hammes, P.S., Alemu, G., 2006. Application of Farmyard Manure Improved the Chemical and Physical Properties of the Soil in a Semi-Arid Area in Ethiopia. Biol. Agric. Hortic. 24, 293-300. https://doi.org/10.1080/01448765.2006. 9755027

Bhattacharyya, R., Kundu, S., Prakash, V.,
Gupta, H.S., 2008. Sustainability under combined application of mineral and organic fertilizers in a rainfed soybeanwheat system of the Indian Himalayas. Eur. J. Agron. 28, 33-46. https://doi.org/10.1016/j.eja.2007.04.00 6

Böhme, L., Langer, U., Böhme, F., 2005. Microbial biomass, enzyme activities and microbial community structure in two European long-term field experiments. Agric. Ecosyst. Environ. 109, 141-152. https://doi.org/10.1016/j.agee.2005.01.0 17

Brennan, E.B., Acosta-Martinez, V., 2019. Cover Crops and Compost Influence Soil Enzymes during Six Years of Tillage-Intensive, Organic Vegetable Production. Soil Sci. Soc. Am. J. 83, 624-637.

https://doi.org/10.2136/sssaj2017.12.04 12

Chang, E.-H., Chung, R.-S., Tsai, Y.-H., 2007. Effect of different application rates of organic fertilizer on soil enzyme activity and microbial population. Soil Sci. Plant Nutr. 53, 132-140. https://doi.org/10.1111/j.17470765.2007.00122.x

Chaudhary, M., Narwal, R.P., 2005. Effect of long-term application of farmyard manure on soil micronutrient status. Arch. Agron. Soil Sci. https://doi.org/10.1080/0365034050013 3134

Das, B.B., Dkhar, M.S., 2011. Rhizosphere Microbial Populations and Physico Chemical Properties as Affected by Organic and Inorganic Farming Practices. Environ. Sci 10, 140-150.

Datt, N., Dubey, Y.P., Chaudhary, R., 2013. Studies on impact of organic, inorganic and integrated use of nutrients on symbiotic parameters, yield, quality of French-bean (Phaseolus vulgaris L.) 
vis--vis soil properties of an acid alfisol. African J. Agric. Res. 8, 2645-2654. https://doi.org/10.5897/AJAR12.942

Davari, M.R., Sharma, S.N., 2010. Effect of different combinations of organic materials and biofertilizers on productivity, grain quality and economics in organic farming of basmati rice (Oryza sativa). Indian $\mathrm{J}$. Agron. 7, 26-35.

Devi, K.N., Singh, T.B., Athokpam, H.S., Singh, N.B., Shamurailatpam, D., 2013. Influence of inorganic, biological and organic manures on nodulation and yield of soybean (Glycine max Merril L.) and soil properties. Aust. J. Crop Sci. 7, 1407.

DOA, 2019. Annual Report 2018-19, Ministry of Agriculture and Family Welfare, Government of India, New Delhi. New Delhi.

Dotaniya, M.L., Datta, S.C., Biswas, D.R., Kumar, K., 2014. Effect of organic sources on phosphorus fractions and available phosphorus in Typic Haplustept. J. Indian Soc. Soil Sci. 62, 80-83.

Dubey, R., Sharma, R.S., Dubey, D.P., 2014. Effect of organic, inorganic and integrated nutrient management on crop productivity, water productivity and soil properties under various rice-based cropping systems in Madhya Pradesh, India. Int. J. Curr. Microbiol. Appl. Sci. 3, 381-389.

Edmeades, D.C., 2003. The long-term effects of manures and fertilisers on soil productivity and quality: A review. Nutr. Cycl. Agroecosystems 66, 165180.

https://doi.org/10.1023/A:10239998166 90

Gupta, A.P., Narwal, R.P., Antil, R.S., Dev, S., 1992. Sustaining soil fertility with organic- $\mathrm{C}, \mathrm{N}, \mathrm{P}$, and $\mathrm{K}$ by using farmyard manure and fertilizer- $\mathrm{N}$ in a semiarid zone: A long- term study. Arid Soil Res. Rehabil. 6, 243-251. https://doi.org/10.1080/1532498920938 1318

Hellal, F.A., Zewainy, R.M., Khalil, A.A., Ragab, A.A.M., 2014. Effect of organic and bio-fertilizer management practices on nutrient availability and uptake by Faba bean-maize sequence. Am. J. Sustain. Agric. 8, 35-42.

Kanwar, K., Paliyal, S.S., Nandal, T.R., 2002. Integrated nutrient management in cauliflower (Pusa Snow Ball K-1). Res. Crop. 3, 579-583.

Katkar, R.N., Sonune, B.A., Kadu, P.R., 2011. Long-term effect of fertilization on soil chemical and biological characteristics and productivity under sorghum (Sorghum bicolor)-wheat (Triticum aestivum) system in Vertisol. Indian J. Agric. Sci. 81, 734-739.

Khandagle, A., Dwivedi, B.S., Aher, S.B., Dwivedi, A.K., Yashona, D.S., Jat, D., 2019a. Effect of long-term application of fertilizers and manure on soil properties. J. Soils Crop. 29, 97-104.

Khandagle, A., Dwivedi, B.S., Aher, S.B., Dwivedi, A.K., Yashona, D.S., Mohbe, S., Panwar, S., 2019b. Distribution of nitrogen fractions under long term fertilizer and manure application in a Vertisol. Biosci. Biotechnol. Res. Commun. 12, 186-193. https://doi.org/http://dx.doi.org/10.2178 6/bbrc/12.1/25

Lakaria, B.L., Singh, M., Reddy, K.S., Biswas, A.K., Jha, P., Chaudhary, R.S., Singh, A.B., Rao, A.S., 2012. Carbon addition and storage under integrated nutrient management in soybean-wheat cropping sequence in a vertisol of Central India. Natl. Acad. Sci. Lett. https://doi.org/10.1007/s40009-0120040-z

Mader, P., 2002. Soil Fertility and Biodiversity in Organic Farming. 
Science (80-.). 296, 1694-1697. https://doi.org/10.1126/science.1071148

Mandal, A., Patra, A., Singh, D., Swarup, A., Ebhinmasto, R., 2007. Effect of longterm application of manure and fertilizer on biological and biochemical activities in soil during crop development stages. Bioresour. Technol. 98, 3585-3592. https://doi.org/10.1016/j.biortech.2006. 11.027

Mandale, P., Lakaria, B.L., Aher, S.B., Singh, A.B., Gupta, S.C., 2019a. Temporal dynamics of nitrogen acquisition in maize cultivars grown under organic-N supply. J. Soils Crop. 29, 52-57.

Mandale, P., Lakaria, B.L., Aher, S.B., Singh, A.B., Gupta, S.C., 2019b. Phosphorous concentration and uptake in maize varieties cultivated under organic nutrient management. Int. J. Agric. Stat. Sci. 15, 311-315.

Mandale, P., Lakaria, B.L., Aher, S.B., Singh, A.B., Gupta, S.C., 2018a. Performance evaluation of maize cultivars for organic production. J. Pharmacogn. Phytochem. 7, 2433-2440.

Mandale, P., Lakaria, B.L., Aher, S.B., Singh, A.B., Gupta, S.C., 2018b. Potassium concentration, uptake and partitioning in maize (Zea mays L.) cultivars grown in organic agriculture. Res. Crop. 19, 587-592.

https://doi.org/10.31830/2348-

7542.2018.0001.34

Mandale, P., Lakaria, B.L., Gupta, S.C., Singh, A.B., Aher, S.B., Sirwaiya, S., 2018c. Growth and yield response of maize cultivars to organic farming in central India. Pharma Innov. J. 7, 138142.

Mandic, L., Djukić, D., Beatovic, I., Jovovic, Z., Pesakovic, M., Stevovic, V., 2011. Effect of different fertilizers on the microbial activity and productivity of soil under potato cultivation. African J.
Biotechnol. 10, 6954-6960. https://doi.org/10.5897/AJB11.947

Mann, K.K., Brar, B.S., Dhillon, N.S., 2006. Influence of long-term use of farmyard manure and inorganic fertilizers on nutrient availability in a Typic Ustochrept. Indian J. Agric. Sci. 76, 477-480.

Manna, M.C., Swarup, A., Wanjari, R.H., Ravankar, H.N., Mishra, B., Saha, M.N., Singh, Y.V., Sahi, D.K., Sarap, P.A., 2005. Long-term effect of fertilizer and manure application on soil organic carbon storage, soil quality and yield sustainability under sub-humid and semi-arid tropical India. F. Crop. Res. 93, 264-280. https://doi.org/10.1016/j.fcr.2004.10.00 6

Mishra, D.M., Sharma, P.K., Aher, S.B., 2014. Kinetics of nitrogen mineralization in sewage amended soil. Int. J. Agric. Environ. Biotechnol. 7, 797-803. https://doi.org/10.5958/2230732x.2014.01389.8

Mugwe, J., Mugendi, D., Mucheru-Muna, M., Odee, D., Mairura, F., 2009. Effect of selected organic materials and inorganic fertilizer on the soil fertility of a Humic Nitisol in the central highlands of Kenya. Soil Use Manag. https://doi.org/10.1111/j.14752743.2009.00244.x

Nagar, R.K., Goud, V. V, Kumar, Rajesh, Kumar, Ravindra, 2016. Effect of organic manures and crop residue management on physical, chemical and biological properties of soil under pigeonpea based intercropping system. Int. J. Farm Sci. 6, 101-113.

Nakhro, N., Dkhar, M.S., 2010. Impact of Organic and Inorganic Fertilizers on Microbial Populations and Biomass Carbon in Paddy Field Soil. J. Agron. 9, 102-110. https://doi.org/10.3923/ja.2010.102.110 
Pikuła, D., Rutkowska, A., 2014. Effect of leguminous crop and fertilization on soil organic carbon in 30-years field experiment. Plant, Soil Environ. 60, 507-511. https://doi.org/10.17221/436/2014-PSE

Prajapat, K., Vyas, A.K., Dhar, S., 2014. Productivity, profitability and land-use efficiency of soybean (Glycine max)based cropping systems under different nutrient-management practices. Indian J. Agron. 59, 229-234.

Raghuveer, Baghel, S.S., Puri, G., Aher, S.B., Jatav, R.C., 2017. Targeted yield concept based fertilizer recommendation for garlic (Allium sativum L.) in black soil of Madhya Pradesh. Int. J. Pure Appl. Biosci. 5, 678-689.

https://doi.org/10.18782/2320-

7051.2691

Rajput, P.S., Srivastava, S., Sharma, B.L., Sachidanand, B., Dey, P., Aher, S.B., Yashona, D.S., 2016. Effect of soil-testbased long-term fertilization on soil health and performance of rice crop in Vertisols of central India. Int. J. Agric. Environ. Biotechnol. 9, 801-806. https://doi.org/10.5958/2230732x.2016.00102.9

Rama Lakshmi, C.S., Sreelatha, T., Usha Rani, T., Rao, S.R.K., Naidu, N. V., 2011. Effect of organic manures on soil fertility and productivity of sugarcane in North Coastal Zone of Andhra Pradesh. Indian J. Anim. Res. 45, 307-313.

Ramesh, P., Panwar, N.R., Singh, A.B., Ramana, S., 2008. Effect of organic manures on productivity, soil fertility and economics of soybean (Glycine max)-durum wheat (Triticum durum) cropping system under organic farming in Vertisols. Indian J. Agric. Sci. 78, 351-354.

Ramesh, P., Raten Panwar, N., Bahadur Singh, A., Ramana, S., Subba Rao, A.,
2009. Impact of organic-manure combinations on the productivity and soil quality in different cropping systems in central India. J. Plant Nutr. Soil Sci. 172, 577-585. https://doi.org/10.1002/jpln.200700281

Satyanarayana, V., Vara Prasad, P. V., Murthy, V.R.K., Boote, K.J., 2002. Influence of integrated use of farmyard manure and inorganic fertilizers on yield and yield components of irrigated lowland rice. J. Plant Nutr. 25, 20812090. https://doi.org/10.1081/PLN120014062

Sienkiewicz, S., Żarczyński, P., Krzebietke, S., Wojnowska, T., Omilian, M., 2009. Effect of long-term differentiated fertilization with farmyard manure and mineral fertilizers on the content of available forms of $\mathrm{P}, \mathrm{K}$ and $\mathrm{Mg}$ in soil. J. Elem. 14, 779-786. https://doi.org/10.5601/jelem.14.4.779786

Singh, A.B., Ramesh, P., Panwar, N.R., Ramana, S., 2008. Nutritional quality of soybean (Glycine max), wheat (Triticum durum) and chickpea (Cicer arietinum) and soil biological properties as influenced by different organic manures. Indian J. Agric. Sci. 78, 781784.

Singh Brar, B., Singh, J., Singh, G., Kaur, G., 2015. Effects of Long Term Application of Inorganic and Organic Fertilizers on Soil Organic Carbon and Physical Properties in Maize-Wheat Rotation. Agronomy 5, 220-238. https://doi.org/10.3390/agronomy50202 20

Singh, G., Sekhon, H.S., Kaur, H., 2012. Effect of Farmyard Manure, Vermicompost and Chemical Nutrients on Growth and Yield of Chickpea (Cicer arietinum L.). Int. J. Agric. Res. 7 , 93-99. https://doi.org/10.3923/ijar.2012.93.99 
Singh, M., Tripathi, A.K., Kundu, S., Takkar, P.N., 1999. Nitrogen requirement of soybean (Glycine max) - wheat (Triticum aestivum) cropping system and biological $\mathrm{N}$ fixation as influenced by integrated use of fertilizer $\mathrm{N}$ and farmyard manure in Typic Haplustert. Indian J. Agric. Sci. 69, 379-381.

Singh, R., Athokpam, H., Changteand, Z., Singh, N., 2005. Integrated management of Azolla, vermicompost and urea on yield of and nutrient uptake by rice and soil fertility. J. Indian Soc. Soil Sci. 53, 107-110.

Sudhakaran, M., Ramamoorthy, D., Kumar, S., 2013. Impacts of conventional, sustainable and organic farming system on soil microbial population and soil biochemical properties, Puducherry, India. Int. J. Environ. Sci. 4, 28-41.

Sushila, R., Giri, G., 2000. Influence of farmyard manure, nitrogen and biofertilizers on growth, yield attributes and yield of wheat (Triticum aestivum) under limited water supply. Indian J. Agron. 45, 590-595.

Swarup, A., 2010. Integrated Plant Nutrient

Supply and Management Strategies for Enhancing Soil Quality, Input Use Efficiency and Crop Productivity. J. Indian Soc. Soil Sci. 58, 25-31.

Urkurkar, J.S., Tiwari, A., Chitale, S., Bajpai, R.K., 2010. Influence of long-term use of inorganic and organic manures on soil fertility and sustainable productivity of rice (Oryza sativa) and wheat (Triticum aestivum) in Inceptisols. Indian J. Agric. Sci. 55, 6-10.

Verma, G., Sharma, R.P., Sharma, S.P.,
Subehia, S.K., Shambhavi, S., 2012. Changes in soil fertility status of maizewheat system due to long-term use of chemical fertilizers and amendments in an alfisol. Plant, Soil Environ. 58, 529533. https://doi.org/10.17221/133/2012PSE

Wanjari, R.H., Singh, M. V., Ghosh, P.K., 2004. Sustainable yield index: An approach to evaluate the sustainability of long-term intensive cropping systems in India. J. Sustain. Agric. https://doi.org/10.1300/J064v24n04_05

Yashona, D.S., Bangar, K.S., Aher, S.B., Rajput, P.S., 2016. Effect of tubewell and sewage water on cadmium adsorption behaviour in soils of Malwa Region of Madhya Pradesh. J. Indian Soc. Soil Sci. 64, 6-12. https://doi.org/10.5958/09740228.2016 .00002 .5

Yashona, D.S., Mishra, U.S., Aher, S.B., 2018a. Response of pigeonpea (Cajanus cajan) to sole and combined modes of zinc fertilization. J. Pharmacogn. Phytochem. 7, 2703-2710.

Yashona, D.S., Mishra, U.S., Aher, S.B., 2018b. Response of pulse crops to sole and combined mode of zinc application: a review. J. Soils Crop. 28, 249-258.

Yashona, D.S., Mishra, U.S., Aher, S.B., Tripathi, A., Sirothia, P., 2018c. Protein and zinc concentration in pigeonpea (Cajanus cajan) under various mode of zinc application. Indian J. Agric. Biochem. 31, 186-194. https://doi.org/10.5958/09744479.2018.00031.X

\section{How to cite this article:}

Dotaniya, C. K., D. S. Yashona, S. B. Aher, P. S. Rajput, R. K. Doutaniya, M. Lata and Mohbe, S. 2020. Crop Performance and Soil Properties under Organic Nutrient Management. Int.J.Curr.Microbiol.App.Sci. 9(04): 1055-1065. doi: https://doi.org/10.20546/ijcmas.2020.904.125 